\title{
Ovicidal and Larvicidal Activities of Ethanolic Leaf Extracts of Three Botanicals Against the Malaria Vector - Anopheles Gambiae
}

\author{
Funmilayo Bukola Egunjobi ${ }^{1 *}$, Ikem Chris Okoye ${ }^{2}$ \\ ${ }^{1}$ Department of Biological Sciences, Tai Solarin University of Education, P.M.B 2118, \\ Ijebu ode, Ogun State, Nigeria. \\ ${ }^{2}$ Department of Zoology and Environmental Biology, University of Nigeria, P.O Box 3236, \\ Nsukka, Enugu State, Nigeria
}

* Corresponding author email: ogunkomayaf@gmail.com

Received: 19 November 2019 / Revised: 17 January 2020 / Accepted: 07 March 2020 / Published: 10 March 2020

\begin{abstract}
Malaria, transmitted by Anopheles gambiae, has been a major public health concern in Africa. Chemicals used in the control of $A$. gambiae have caused a lot of havoc in the environment and to non-target organisms. More so, a high rate of resistance by these mosquitoes has been recorded. This study evaluated the ovicidal and larvicidal activities of ethanolic leaf extracts of Duranta erecta, Tridax procumbens and Pennisetum purpureum against $A$. gambiae. Phytochemical analysis of these plants revealed the presence of tannins, saponins, alkanoids, flavonoids, glycosides and anthroquinone. Ground dry leaves of each plant material were concentrated in 7 litres of $95 \%$ ethanol for 72 hours followed by filtration and evaporation. D. erecta, T. procumbens and P. purpureum yielded 617.2g, 598.3g and 552g of extracts respectively. The WHO standard for mosquito bioassay was adopted and concentrations 40, 100, 140 and 200 parts per million (PPM) were tested against 20 eggs and 25 larvae using emersion method. The hatching rate and \% larval mortality of the extracts were recorded in which a concentration dependent increase was observed. High ovicidal activity (low egg hatchability) was recorded in D. erecta ( $\left.\mathrm{LC}_{50}-10.037 \mathrm{PPM}\right)$ followed by P. purpureum and T. procumbens with $\mathrm{LC}_{50}$ values of 17.380 and 39.198 respectively. The highest larvicidal activity was observed in $D$. erecta $\left(\mathrm{LC}_{50}-76.943\right.$ PPM) compared to P. purpureum and T. procumbens (LC 50 - 213.410 PPM and 214.217 PPM). Evidently, $D$. erecta ethanolic leaf extracts showed the best efficacy in the control of $A$. gambiae in this study. $D$. erecta is an environmentally friendly alternative in reducing the use of chemicals for mosquito control.
\end{abstract}

Keywords: Anopheles gambiae, Duranta erecta, Tridax procumbens, Pennisetum purpureum, Mosquito, Larvicidal, Ovicidal, Mosquito, Malaria

\section{Introduction}

Malaria is one of the serious scourges inflicted upon humanity causing high level of mortality along with great financial losses. Malaria and filariasis rank among the world most prevalent tropical infectious diseases, [1] with malaria being the most important vector borne disease in the world [2]. Globally, malaria infects more than 500 million humans each year [3] with one or two million deaths reported annually [3][4]. In 2015, 3.3 billion people in 97 countries were reported by World Health Organization [5] to be at risk of malaria with an estimated number of 200 million cases and 600, 000 deaths and in 2016, there was an increase of over 5 million cases.

In $2015,90 \%$ of the malaria cases were reported in sub-Saharan Africa and $92 \%$ of the malaria deaths were reported worldwide. Two countries in sub-Sahara Africa, Nigeria and Republic of Congo have been reported to have contributed to high malaria burden, as $36 \%$ of the malaria cases worldwide occurred in the two countries. More so, the prevalence was reduced by half and the incidence of clinical disease fell by $40 \%$ between 2000 and 2015[6] owing to the use of mosquito treated nets. However, malaria still remains a 
major health problem in sub-Saharan Africa countries [1].

In Nigeria, the entire population has been reported to be at risk of malaria. In 2009 the World Health Organization reported 4,295,686 confirmed cases, 658,732 were inpatient malaria cases and 7,522 malaria attributed deaths [2]. Furthermore, in 2016 malaria killed more than 100, 000 people in Nigeria [7].

Anopheles gambiae is the major vector of Plasmodium falciparium - the causal agent of malaria - in Africa, thus, it is commonly called the African malaria mosquito. Its blood meal come almost exclusively from human, its larvae develop in temporary bodies of water produced by human activities through agricultural irrigation, flooded human or domestic animal footprints among others while adults rest primarily in human dwellings. A. gambiae complex comprises six named species which include: $A$. arabiensis, $A$. bwanbae, A. melas, $A$. merus, $A$. quadriannulatus and Anopheles gambiae sensu stricto; one unnamed species and several 'incipient' species [8].

Various cultural control measures targeted at reducing and eradicating the breeding sites of mosquitoes have been suggested and implemented over the years. Synthetic insecticides such as the organochlorines, organophosphates, and cabamates proved very effective until their havoc to the environment and non-target species were discovered. There are many negative impacts and short comings of these strategies which include environmental pollution, dangers to non-target organisms and most importantly the development of resistance in mosquitoes. There is still needed to search for more stable and effective technique to end the malaria scourge in Africa.

It has been discovered that plants generally produce many secondary metabolites which constitute an important source of microbicides, pesticides and many pharmaceutical drugs [9]. Varieties of plants such as Citrus paradise [10], Clausena anisate [11], Zanthoxylum heitsii [12], Lippia adoensis [13], Chromolaena odorata [14], Ageratum conyzoides [15] with insecticidal activities have been reported.

Duranta erecta (Linn), also known as golden dewdrop, pigeon berry, angel whisper, or sky flower in English, is a shrub usually 1 to $3 \mathrm{~m}$ in height. It is a native plant of Southern America, Mexico, Central America, Caribbean, and other areas that spread throughout the tropical and warm subtropical regions and the most common ornamental plant in south western Nigeria [16].

$D$. erecta has been shown to possess various antimicrobial, antioxidant and insecticidal properties [17]. It contains various primary and secondary metabolites such as glycoside, saponins, sterols, flavonoids, phenols, tannins, alkaloids, carbohydrates and proteins. Saponins in the fruits and foliage cause gastro enteric irritation, drowsiness, fever nausea, vomiting, and convulsions [18]. Few studies have been published on the bio-efficacy of $D$. erecta against some different developmental stages of mosquitoes. The bio-efficacy of its leaf extracts only on the eggs and larvae of the yellow fever and dengue vector- Aedes aegypti [19] and its efficacy as a larvicidal agent against Culex quinquefasciatatus [20] have been reported.

Pennisetum purpureum commonly known as napier grass or elephant grass, is a native grass species in the tropical grasslands of Africa which is spreading rapidly in many parts of the world. It is a major forage crop in the wet tropics of the world [21]. It is named elephant grass because it is mainly used for feeding elephants in Africa. Its widespread occurrence may be attributed to its aggressive behaviour, very high seed production potential and suppressive effects on neighbouring plants through allelopathic interactions [21].

$P$. purpureum contains several phytotoxic chemicals which also makes it a potential herbicide [21]. It is rich in tannin, alkaloids, flavonoids and saponins with tannin having the highest concentration [22] which have conferred upon it antimicrobial, anti- inflammatory, antioxidant, anti-allergic, hepatoprotective, antithrombic, antiviral and anti-carcinogenic properties. No published work has been done on the bio efficacy of $P$. purpureum extracts as insecticide on any class of insects.

Tridax procumbens Linn. is a common grass, a native of tropical America which naturalized in tropical Africa, Asia, and Australia. It is found in tropical southern part of Nigeria, growing 
Egunjobi et al., Int. Ann. Sci.; Vol. 9, Issue 1, pp: 111-121, 2020

primarily during raining season and also throughout India [23].

T. procumbens contains different secondary metabolites. Chloroform extract of the leaves shows the presence of Steroid, Saponin, Coumarins, Alkaloids, Amino acids, Diterpenes, Phenol and Flavonoids while the Acetone-Water extract shows the presence of Steroid, Tannin, Saponin, Anthocyanin, Coumarins, Alkaloids, Diterpenes, Phenol and Flavonoids [23]. High flavonoids, alkaloids, hydroxycinnamates, tannins and phytosterols, moderate benzoic acid derivatives and lignans, and low carotenoids contents in T. procumbens have been reported [24]. The presence of these phytochemicals portrays the potential of $T$. procumbens as a healthpromoting food, food supplements and an insecticide.

Primary and secondary metabolites extracted from plants have the potential to be used as effective and ecofriendly control agents for mosquito vectors [25]. Several groups of these phytochemicals such as alkaloids, steroids, terpenoids, essential oils and phenolics from different plants have been reported previously for their insecticidal activities [26]. They are extracted either from the whole body of little herbs or from various parts like fruits, leaves, stems, barks, roots, etc., of larger plants or trees [27]. Naturallyoccurring phyto-compounds that are rich sources of bioactive chemicals appear to be the most likely candidates for the environmentally safe and degradable products targeted specifically against mosquitoes [28], especially those that cause Malaria.

No published work has been repoorted on the efficacy of D. erecta, P. purpureum and T. procumbens against the different stages of $A$. gambiae. Therefore, this study focused on evaluating the ovicidal and larvicidal activities of $D$. erecta, $T$. procumbens and $P$. purpureum extracts against the malaria vector $-A$. gambiae.

\section{Materials and Methods}

\subsection{Collection and Identification of Plant Materials}

Fresh leaves of $D$. erecta, T. procumbens and $P$. purpureum were collected from the residential quarters within the University of Nigeria,
Nsukka. Identification of the plants was verified at the International Centre for Ethnomedicin and Drug Development, Nsukka. Sample specimen of the leaves of each plant were deposited in the herbarium and allocated a voucher number, InterCEDD/16292, InterCEDD/16291 and InterCEDD/844 for D. erecta, T. procumbens and $P$. purpureum respectively.

\subsection{Preparation of Plant Extracts}

The plant samples were washed with tap water and then surface sterilized in 10\% sodium hypochlorite to prevent contamination of any microbes. Thereafter, the plant materials were washed with tap water to remove all the unwanted impurities and finally they were thoroughly rinsed with sterile distilled water and then, the plant materials were dried under room temperature $\left(20^{\circ} \mathrm{C}\right)$ followed by oven drying by an electric oven at $60{ }^{\circ} \mathrm{C}$ for half an hour. The oven dried plant materials were grind using electric blender and the powdered materials were packed in air-lock plastic containers.

\subsection{Preparation of Concentrated Extracts of Plant Materials}

$1 \mathrm{~kg}$ of dried and ground leaves of each plant were concentrated in 7 liters of $95 \%$ ethanol each and separately. D. erecta, T. procumbens and P. purpureum yielded $617.2 \mathrm{~g}, 598.3 \mathrm{~g}$ and $552 \mathrm{~g}$ of extracts respectively. They were allowed to stay for 72 hours before filtration. The plant extracts were filtered using a funnel packed with cotton wool. The filtered extracts were thereafter evaporated to dryness using a rotary evaporator. The concentrated extracts were stored in a refrigerator until use.

\subsection{Phytochemical screening}

The qualitative phytochemical screening for alkaloids and phenols were conducted using the analytical methods of Khalid et al [29]; flavonoids, tannins and glycosides screening done using the methods of Ajuru et al. [30]; saponins and phytosteroids, with the methods of Mumtaz and Raza [31] while proteins, carbohydrates and triterpenoids were studied using the methods of Bandiola [32]. 


\subsection{Test Organism}

Anopheles gambiae eggs were recruited from the egg colony at the Arthropod Borne Viral Diseases (ARBOVIRUS) Center, Ministry of Health, Enugu State, Nigeria. The eggs were reared to larvae and adults for the larvicidal bioassays and repellent activities, at the Entomology Laboratory of the University of Nigeria Nsukka, Nigeria.

\subsection{Larval Rearing of A. gambiae Eggs}

The mosquito larvae were hatched from the egg colony using modified methods of Agwu et al [19]. The eggs were washed with $5 \mathrm{ml}$ of $0.01 \%$ formaldehyde solution for 30 minutes in a $500 \mathrm{ml}$ distilled water, as a precaution against possible microsporidian infections which might interfere with the normal development of the immature stages of mosquitoes and soaked in water to facilitate hatching. After hatching, the first instar larvae stages were distributed in buckets $40 \mathrm{~cm}$ in diameter and $15 \mathrm{~cm}$ in depth. The containers were large enough in size to prevent overcrowding until development to early 4th instar larvae which is the required larvae stage for the study. The larvae were kept in the plastic buckets half filled with tap water and fed with larval food (powdered white oats and yeast in the ratio of 3:1) once a day initially at the beginning of the experiment and twice during the later stages of development. In order to prevent scum from forming on the water surface, water in rearing container was refreshed every day by removing a little quantity of water from the rearing buckets and replacing with fresh water. The mouth of the buckets was all covered with bridal net held in place with a rubber band to prevent unwanted mosquitoes from laying eggs in the plastic buckets.

\subsection{Preparation of Plant Extracts Solutions for Bio-assay Experiments}

The ovicidal and larvicidal potential of the leaf extracts against $A$. gambiae were observed using the standard procedures recommended by the World Health Organization [33]. The stock solution (20 $\mathrm{ml}$ of $1 \%$ ) of each plant extracts was prepared by weighing $200 \mathrm{mg}$ of the extract and adding $20 \mathrm{ml}$ solvent (ethanol). Thereafter, the stock solution was serially diluted in ten-fold ethanol ( $2 \mathrm{ml}$ solution to $18 \mathrm{ml}$ solvent).

\subsection{Determination of Test Concentrations of the Plant Extracts}

The mosquito eggs and larvae were initially exposed to a wide range of test concentrations $(0.1-2.0 \mathrm{ml}$ of extract solution in $200 \mathrm{ml}$ of distilled water) and a control to establish the activity range of the plant materials under test. After determining the mortality of larvae in this wide range of concentrations, a narrower range of 4 aliquots $(0.4 \mathrm{ml}, 1.0 \mathrm{ml}, 1.4 \mathrm{ml}$ and $2.0 \mathrm{ml})$ yielding between $10 \%$ and $95 \%$ mortality in $24 \mathrm{~h}$ were used to determine $\mathrm{LC}_{50}$ and $\mathrm{LC}_{90}$ values. Three replicates and an equal number of controls were set up for each concentration simultaneously with tap water, to which $1 \mathrm{ml}$ of ethanol was added.

\subsection{Experimental Design and Procedure for Bioassay Experiment}

The bioassay was performed at room temperature of $26 \pm 2{ }^{\circ} \mathrm{C}$ and relative humidity of $80 \pm 2 \%$ and a photoperiod of $12 \mathrm{~h}$ light followed by $12 \mathrm{~h}$ dark (12L:12D) for 48 hours.

\subsubsection{Ovicidal Bioassay}

Twenty five $A$. gambiae eggs were introduced into the plastic container containing $200 \mathrm{ml}$ distilled water. The setup was left for 48 hours. The larvae hatched were visually observed and recorded. The rate of hatching for each treatment level was calculated using the formulae below:

Hatching Rate

$=\frac{\text { Number of hatched eggs }}{\text { Total number of eggs used in each treatment }} \times 100$

\subsubsection{Larvicidal bioassay}

Twenty five $A$. gambiae $4^{\text {th }}$ instar larvae were introduced into the plastic container which contains $200 \mathrm{ml}$ of distilled water by means of a dropper. Small, unhealthy or damaged larvae were all removed and replaced. After $24 \mathrm{~h}$ exposure, larval mortality was recorded. Moribund larvae were counted and added to dead larvae for calculating percentage mortality. Dead larvae were those that cannot be induced to move when they are probed with a needle in the siphon or the cervical region. Moribund larvae are those incapables of rising to the surface or not showing 
Egunjobi et al., Int. Ann. Sci.; Vol. 9, Issue 1, pp: 111-121, 2020

the characteristic diving reaction when the water is disturbed. The results were recorded on the form recommended by the World Health Organization. Percentage of mortality of the larvae were calculated using the formula below:

$$
\% \text { Mortality }=\frac{\text { Number of Larvae Dead }}{\text { No. of larvae }} \times 100
$$

\subsection{Statistical analysis}

The hatching rate and percentage of mortality data were subjected to a One-way analysis of variance (ANOVA) to compare the means. A post hoc test - Duncan test of multiple comparisons - was used to determine the significant differences between the treatments. Probit analysis was used to determine lethal dosages causing 50\% ( $\left.\mathrm{LC}_{50}\right)$ and 90\% (LC 90 ) mortality. All statistical analyses were done using the SPSS (Statistical Package of Social Sciences) software version 22 . Results with $\mathrm{P}<0.05$ were considered to be statistically significant.

\section{Results}

\subsection{Phytochemical screening}

The phytochemical screening of the ethanol extracts of D. erecta, T. procumbens and P. purpureum extracts revealed the presence of alkaloids, flavonoids, tannins, saponins and carbohydrates. Phenols were only found to be present in the extracts of D. erecta; Glycosides and triterpenoids were found in both $D$. erecta and $P$. purpureum but absent in T. procumbens; while phytosteroids and proteins were discovered in $T$. procumbens and $P$. purpureum but found to be absent in $D$. erecta (Table 3.1).

\subsection{Ovicidal Bioassay}

The three plant extracts tested (D. erecta, $T$. procumbens and $P$. purpureum) partially inhibited the hatchability of the Anopheles eggs exposed to them. However, there were recorded variations in the rate of hatching in the three plants tested as shown in Table 3.2. This indicated that D. erecta, T. procumbens and $P$. purpureum are potential ovicides. Only $12.92 \%$ of the eggs exposed to $D$. erecta extracts hatched while $21.25 \%$ and $30.83 \%$ hatched in treatments containing $P$. purpureum and T. procumbens leaf extracts (Table 3.3).

Table 3.1: Phytochemical compounds present in ethanol extracts of the leaves of D. erecta

\begin{tabular}{|l|c|c|c|}
\hline $\begin{array}{l}\text { Phytochemical } \\
\text { constituents }\end{array}$ & $\begin{array}{l}\text { D. } \\
\text { erecta }\end{array}$ & $\begin{array}{l}\text { T. } \\
\text { procumbens }\end{array}$ & $\begin{array}{l}\text { P. } \\
\text { purpureum }\end{array}$ \\
\hline Alkaloids & + & + & + \\
\hline Flavonoids & + & + & + \\
\hline Tannins & + & + & ++ \\
\hline Saponins & ++ & + & + \\
\hline Steroids & - & + & ++ \\
\hline Phenols & ++ & - & - \\
\hline Glycosides & + & - & + \\
\hline Triterpenoids & ++ & - & + \\
\hline Proteins & - & ++ & + \\
\hline Carbohydrates & + & + & + \\
\hline
\end{tabular}

Keys: (-) absence; (+) small quantity; (++) moderately

Table 3.2: Mean hatching rate of A. gambiae eggs exposed to extracts

\begin{tabular}{|l|l|l|l|}
\hline $\begin{array}{l}\text { Concentration } \\
(\text { PPM })\end{array}$ & Rate \pm SD & \multicolumn{2}{|c|}{ Mean Hatching } \\
& D. erecta & T. procumbens & P. purpureum \\
\hline 40 & $20.00 \pm 5.00^{\mathrm{b}}$ & $46.67 \pm 17.56^{\mathrm{ab}}$ & $31.67 \pm 5.77^{\mathrm{b}}$ \\
100 & $18.33 \pm 2.89^{\mathrm{b}}$ & $36.67 \pm 17.56^{\mathrm{ab}}$ & $25.00 \pm 5.00^{\mathrm{b}}$ \\
140 & $13.33 \pm 2.89^{\mathrm{b}}$ & $25.00 \pm 13.23^{\mathrm{ab}}$ & $21.67 \pm 5.77^{\mathrm{b}}$ \\
200 & $0.00 \pm 0.00^{\mathrm{a}}$ & $15.00 \pm 8.66^{\mathrm{a}}$ & $6.67 \pm 2.89^{\mathrm{a}}$ \\
Control & $58.33 \pm 10.21^{\mathrm{c}}$ & $55.00 \pm 27.83^{\mathrm{b}}$ & $50.00 \pm 10.00^{\mathrm{c}}$ \\
\hline
\end{tabular}

Results with same letters in the column are not significantly different $(\mathrm{P}<0.05)$

Table 3.3: Total Mean Hatching Rate of all Extracts

\begin{tabular}{|c|c|}
\hline Plant & $\begin{array}{c}\text { Total Mean Hatching } \\
\text { Rate } \pm \text { SD }\end{array}$ \\
\hline D. erecta & $12.92 \pm 8.65^{\mathrm{a}}$ \\
T. procumbens & $30.83 \pm 17.68^{\mathrm{b}}$ \\
P. purpureum & $21.25 \pm 10.47^{\mathrm{ab}}$ \\
\hline
\end{tabular}

Results with same letters in the column are not significantly different $(\mathrm{P}<0.05)$

The most active extract was recorded to be $D$. erecta having a lethal concentration capable of inhibiting $50 \%$ of the eggs from hatching $\left(\mathrm{LC}_{50}\right)$ of 10.037 ppm, followed by P. purpureum and $T$. procumbens with $\mathrm{LC}_{50}$ values of 17.380 and 39.198 respectively (Table 3.4).

Table 3.4: Estimates of $L C_{50}$ and $L C_{90}$ values of Plant Extracts against A. gambiae Eggs

\begin{tabular}{|l|l|l|l|l|}
\hline Plants & $\begin{array}{l}\text { LC50 (PPM) and 95\% } \\
\text { confidence interval }\end{array}$ & LC90 $(\mathrm{ppm})$ and 95\% confidence interval & $\mathrm{X}^{2}$ & $\mathrm{df}$ \\
\hline D. erecta & $10.037(0.020-26.808)$ & $124.657(79.043-467.187)$ & 9.475 & 10 \\
T. procumbens & $39.198(1.065-68.125)$ & $412.087(196.370-120495.460)$ & 18.357 \\
$P$. purpureum & $17.380(0.815-35.874)$ & $271.812(160.940-2038.029)$ & 6.530 & 10 \\
\hline
\end{tabular}


Table 3.5: Mean \% mortality of A. gambiae larvae exposed to leaf extracts.

\begin{tabular}{|l|l|l|l|l|l|l|}
\hline \multirow{2}{*}{$\begin{array}{l}\text { Conc. } \\
\text { (PPM) }\end{array}$} & \multicolumn{2}{|c|}{ D. erecta } & \multicolumn{2}{c|}{ T.procumbens } & \multicolumn{2}{c|}{ P. purpureum } \\
\cline { 2 - 7 } & $\begin{array}{l}\text { Mean } \% \\
\text { Mortality } \pm \text { SD }\end{array}$ & $\begin{array}{l}\text { Mean \% survival } \\
\pm \text { SD }\end{array}$ & $\begin{array}{l}\text { Mean } \\
\text { Mortality } \pm \text { SD }\end{array}$ & $\begin{array}{l}\text { Mean } \\
\text { survival } \pm \text { SD }\end{array}$ & $\begin{array}{l}\text { Mean Mortality } \pm \text { SD } \\
\text { Mean } \\
\text { survival } \pm \text { SD }\end{array}$ \\
\hline 40 & $29.33 \pm 8.33^{\mathrm{b}}$ & $70.67 \pm 8.33^{\mathrm{d}}$ & $13.33 \pm 2.31^{\mathrm{b}}$ & $86.67 \pm 2.31^{\mathrm{c}}$ & $10.67 \pm 2.31^{\mathrm{a}}$ & $89.33 \pm 2.31^{\mathrm{d}}$ \\
100 & $53.33 \pm 6.11^{\mathrm{c}}$ & $46.67 \pm 6.11^{\mathrm{c}}$ & $14.67 \pm 2.31^{\mathrm{b}}$ & $85.33 \pm 2.31^{\mathrm{c}}$ & $21.33 \pm 2.31^{\mathrm{b}}$ & $78.67 \pm 2.31^{\mathrm{c}}$ \\
140 & $73.33 \pm 2.31^{\mathrm{d}}$ & $26.67 \pm 2.31^{\mathrm{b}}$ & $33.33 \pm 2.31^{\mathrm{c}}$ & $66.67 \pm 2.31^{\mathrm{b}}$ & $33.33 \pm 8.33^{\mathrm{c}}$ & $66.67 \pm 8.33^{\mathrm{b}}$ \\
200 & $82.67 \pm 2.31^{\mathrm{e}}$ & $17.33 \pm 2.31^{\mathrm{a}}$ & $57.33 \pm 6.11^{\mathrm{d}}$ & $42.67 \pm 6.11^{\mathrm{a}}$ & $53.33 \pm 6.11^{\mathrm{d}}$ & $46.67 \pm 6.11^{\mathrm{a}}$ \\
Control & $5.33 \pm 2.31^{\mathrm{a}}$ & $94.67 \pm 2.31^{\mathrm{e}}$ & $2.67 \pm 2.31^{\mathrm{a}}$ & $97.33 \pm 2.31^{\mathrm{d}}$ & $2.67 \pm 2.31^{\mathrm{a}}$ & $97.33 \pm 2.31^{\mathrm{d}}$ \\
& & & & & & \\
\end{tabular}

Results with same letters in the column are not significantly different $(\mathrm{P}<0.05)$

Table 3.6: Total Mean Percentage Mortality of Larvae in all Extracts

\begin{tabular}{|l|l|}
\hline Plant & Total Mean Mortality \pm SD \\
\hline D. erecta & $59.67 \pm 21.87^{\mathrm{b}}$ \\
T. procumbens & $29.67 \pm 18.87^{\mathrm{a}}$ \\
$P$. purpureum & $29.67 \pm 17.17^{\mathrm{a}}$ \\
\hline
\end{tabular}

Results with same letters in the column are not significantly different $(\mathrm{P}<0.05)$

Table 3.7: Estimates of $L C_{50}$ and $L C_{90}$ values of Plant Extracts against A. gambiae Larvae

\begin{tabular}{|c|c|c|c|c|}
\hline Plants & $\begin{array}{l}\mathrm{LC}_{50}(\mathrm{PPM}) \text { and } 95 \% \text { confidence } \\
\text { interval }\end{array}$ & $\begin{array}{l}\mathrm{LC}_{90}(\mathrm{PPM}) \text { and } 95 \% \text { confidence } \\
\text { interval }\end{array}$ & $\mathrm{X}^{2}$ & $\mathrm{df}$ \\
\hline D. erecta & $76.943(62.300-90.862)$ & $307.764(231.107-496.524)$ & 4.513 & 10 \\
\hline T. procumbens & $214.217(162.031-381.640)$ & $1024.001(509.981-6014.077)$ & 12.192 & 10 \\
\hline P. purpureum & $213.410(169.796-318.820)$ & $1002.144(558.002-3363.794)$ & 5.527 & 10 \\
\hline
\end{tabular}

\subsection{Larvicidal Bioassay}

Different concentrations of plant extracts showed various percentages of mortality. The highest mean mortality rate was recorded in concentration 200 PPM in all extracts, showing a dose dependent increase in mortality. D. erecta increased from 29.33\% - 82.67\% while $T$. prucumbens increased from $13.33 \%$ to $57.33 \%$ and P. purpureum from $10.67 \%$ to $53.33 \%$ (Table 3.5). More so, all concentrations were significantly different at $\mathrm{p}<0.05$. D.erecta displayed the highest larvidical activity with the total mean mortality of 59.67\% while T. procumbens and P. purpureum had same total mean mortality of $29.67 \%$ (Table 3.6). The three plant extracts tested against larvae of A. gambiae were active. However, the most active extract was recorded to be $D$. erecta with an $\mathrm{LC}_{50}$ of $76.943 \mathrm{ppm}$ followed by $P$. purpureum and $T$. procumbens having and $\mathrm{LC}_{50}$ values of $213.410 \mathrm{ppm}$ and 214.217 ppm respectively (Table 3.7).

\section{Discussions}

Different plant species have been identified to contain various phytochemical constituents which are in form of secondary metabolites majorly for the protection of the plants. Various constituents such as saponins, phenols, alkaloids, flavonoids, terpenoids among others have been extracted from plants.

Flavonoids, tannins, saponins were conspicuously present in all the plant extracts tested. Earlier studies have reported that these phytochemicals are present in D. erecta [19] [9] [34] [35], T. procumbens, [23][24][36][37][38] [39] and $P$. purpureum [22][40] [41].

The presence of these chemicals attributes to their ovicidal, and larvicidal effect against Anopheles mosquitoes in this study. Earlier studies had reported saponins, flavonoids and tannins as active biological compounds. Saponins have been identified to possess a range of biological activities such as antimicrobial [42], membranepermeabilising, immunostimulant, hypocholesterolaemic, anticarcinogenic, analgesic, anti-nociceptive, antioxidant, antifungal and antiviral properties [43].

Many flavonoids are shown to have antioxidative activity [44] [45], hepatoprotective, antiinflammatory properties [46][47] developmental 
Egunjobi et al., Int. Ann. Sci.; Vol. 9, Issue 1, pp: 111-121, 2020

regulators [48] antiviral [49] and antifungal activities [50]. They have been used in the areas of infectious diseases including resistant bacterial infections, tuberculosis, opportunistic infections, viral infections, parasitic infections [51]. Tannins are also known for their antiseptic and antimicrobial properties [52][53] and are being tested against various pathogenic organisms [54] and nematodes [55]. Furthermore, there is ample proof of their anti-inflammatory, cicatrizant and anti-HIV functions [56].

Over the years, plant-based products extracted using different solvents such as hexane, chloroform, benzene, petroleum ether, benzene, ethyl acetate, methanol, and water from the leaves have been tested for their ovicidal activities against Anopheles mosquito species.

From the results obtained $D$. erecta leaf extracts showed high level of ovicidal activity at all concentrations, 40,100,140 and 200 ppm with an $\mathrm{LC}_{50}$ value of 10.037 PPM. This indicated a very high potential of this plant as a mosquito ovicide. The effectiveness of this plant could be attributed to the presence of saponin, a phytochemical component known to be insecticidal.

A complete inhibition of egg hatching was observed at 200 PPM in D. erecta extracts. This have been reported in Celosia argentea, Anthocephalus cadamba, Gnetum ula, Solena amplexicaulis and Spermacoce hispida extract against An. stephensi, Ae.aegypti and Cx. Tritaeniorbynchus [57] and leaf extracts of Acalypha indica [58] at 200PPM.

In contrast, zero egg hatchability in the methanol leaf extract of Coccinia indica and Andrographis paniculata was recorded at 150 PPM for $C$. quinquefasciatus [59], methanol extract of Cassia occidentalis and Euphorbia birta [59] 100\% mortality was attained against C. quinquefasciatus and methanol extract of Delonix elata was recorded at 300PPM against $A$. stephensi and A. aegypti [60].

The complete ovicidal activity might be as a result of the plant extract being able to block the micropyle region of the egg, thereby preventing the exchange of gases, which eventually killed the embryo in the egg. The disturbance with egg cytoplasm was reflected in the form of dead eggs with black spot stage due to the arrest of further development of embryo inside the egg [19].

T. procumbens and $P$. purpureum in this study, also displayed a potential of being used an ovicide in mosquito control. An $\mathrm{LC}_{50}$ value of $39.198 \mathrm{ppm}$ and $17.380 \mathrm{ppm}$ were recorded in both plants respectively. More so, a record of a concentration dependent increase was established in all extracts. Similar studies on the ovicidal activities of plants belonging to different families against Anopheles mosquitoes have been reported by various authors with a concentration dependent increase. In the test of the ovicidal potential of $D$. erecta aqueous leaf extracts against the Dengue vector, Aedes aegypti a concentration dependent increase was recorded with an $\mathrm{LC}_{50}$ value of $340.085 \mathrm{PPM}$ [19]. Similar findings have been documented in Boswellia dalrielii leaf extracts [61], ethanolic extract of Artemisia annua [62], leaf acetone, ethyl acetate, and methanolic extracts of Aegle marmelos, Andrographis lineata and Cocculus hirsutus [63], methanolic leaf extract of Cassia fistula [64], leaf extract of Acalypha indica [65] and those of crude hexane, benzene, chloroform, ethyl acetate, and methanol solvent extracts of Delonix elata [60] against Anopheles species.

The increase in the phytochemical constituents present in high concentrations of the plant extract played a remarkable role. Consequently, as the concentration increases, the ovicidal potential of the extract also increases, resulting in an inverse proportionality between the percent hatchability of the eggs and the concentration of extract.

The Larvicidal efficacy of ethanol extracts of $D$. erecta, T. procumbens and $P$. purpureum against $A$. gambiae fourth instar larvae revealed that all the tested plant extracts were active against the test organism, as pupation was inhibited in a considerable number of larvae.

Similar studies on the larvicidal activities of plants belonging to different families have been reported by various authors against the $A$. gambiae larvae including Gnetum ula, Spermacoce hispida [57], Artemisia annua [62], Plumbago zeylanica, Plumbago dawei and Plumbago stenophylla [66], Persea Americana [67], Citrus reticulata, Citrus limon, Citrus aurantifolia, Citrus sinensis, Citrus paradise [10], Clausena anisate [11], Zanthoxylum heitrii [12], Lippia adoensis [13], 
Chromolaena odorata [14], Ageratum conyzoides [15], Ocimum gratissimum [68] and Chenopodium ambrosioides [13] among other plant based larvicides against $A$. gambiae.

The plants were able to inhibit the larvae growth due to the fact that they contain the three main phytochemicals known to possess insecticidal properties in conspicuous amount, including saponins, tannins and alkaloids. Larval mortality might be traced to these phytochemicals. The changes in the activity of the extracts could be attributed to different concentration of phytochemicals in the extracts. The bioactivities demonstrated by the different extracts may also be attributed to uneven distribution of chemical constituents within these extracts. The phytochemicals could have either exhibited synergistic or additive effects when used in their crude form. Secondary compounds of plants may jointly or independently have activity against mosquito targets from their ovicidal and pupicidal, activity against the adult and inhibition of growth activity [19].

$D$. erecta showed the highest larvae mortality in all the tested plant which predisposed it as potential larvicide for mosquito control. Other studies have confirmed its larvicidal potential against $A$. aegypti [19] and Culex quinquefascitatus [35]. This study, to the best of our knowledge, is the first report of $D$. erecta against $A$. gambiae.

The reason behind the high potential of $D$. erecta leaf extracts as mosquito larvicides was due to high composition of saponins present in the extract compared to other plants tested in this study (T. procumbens and P. purpureum). Saponins are freely soluble in water and mostly used in the manufacture of insecticides, vaccines and synthesis of steroidal hormones. Saponins work by interacting with the cuticle membrane of the larvae, changing the microstructure of the cell membranes and finally disrupting the membrane, which is one of the likely reasons for larval death.

\section{Conclusions}

The leaves of $D$. erecta, T. procumbens and $P$. purpureum contain active insecticidal compounds including alkaloids, flavonoids, tannins and saponins which qualify them as potential ovicides and larvicides in the control of mosquitoes. These plants can be used for the development of easily biodegradable ovicides and larvicides which will serve as best alternatives to the expensive, environmentally hazardous and the existing mosquito resistant insecticides. However, further studies on the identification of the major active compounds present in these plants, their modes of action and extensive field trials, are required to further test their efficacy.

\section{Declarations}

\subsection{Acknowledgments}

The authors thank the Arthropod Borne Viral Diseases Center (ABOVIRUS), Enugu State, Nigeria for providing the A. gambiae eggs for the study and some technical assistance.

\subsection{Funding Source}

The study was sponsored by the Malaria Consortium, UK.

\subsection{Competing Interests}

The authors declared that no conflict of interest exist.

\section{How to Cite this Article:}

F. Egunjobi and I. Okoye, "Ovicidal and Larvicidal Activities of Ethanolic Leaf Extracts of Three Botanicals Against the Malaria Vector - Anopheles Gambiae", Int. Ann. Sci., vol. 9, no. 1, pp. 111-121, Mar. 2020. doi: 10.21467/ias.9.1.111-121

\section{References}

[1] K. Krishnappa, K. Elumalai, S. Dhanasekaran, and J. Gokulakrishnan, "Larvicidal and repellent properties of adansonia digitata against medically important human malarial vector mosquito anopheles stephensi (Diptera: Culicidae)," J. Vector Borne Dis., vol. 49, no. 2, pp. 8690, 2012.

[2] WHO, Basic Malaria Microscopy, 2nd ed. WHO Press, World Health Organization, 2010.

[3] K. Kovendan, K. Murugan, S. Vincent, and D. R. Barnard, "Efficacy of larvicidal and pupicidal properties of Acalypha alnifolia Klein ex Willd. (Euphorbiaceae) leaf extract and Metarhizium anisopliae (Metsch.) against Culex quinquefasciatus Say. (Diptera: Culicidae)," J. Biopestic., vol. 5, no. Supplementary, pp. 170-176, 2012.

[4] C. Kamaraj et al., "Larvicidal activity of medicinal plant extracts against Anopheles subpictus and Culex tritaeniorhynchus," Indian J. Med. Res., vol. 134, no. 1, pp. 101-106, 2011.

[5] WHO, "Key facts Who is at risk? Disease burden," 2018.

[6] S. Bhatt et al., "The effect of malaria control on Plasmodium falciparum in Africa between 2000 and 
Egunjobi et al., Int. Ann. Sci.; Vol. 9, Issue 1, pp: 111-121, 2020

2015," Nature, vol. 526, no. 7572, pp. 207-211, 2015.

[7] A. Gulland, “'In Nigeria you can never escape malaria," The Telegraph, 2018.

[8] M. Coetzee, R. H. Hunt, R. Wilkerson, A. D. Torre, M. B. Coulibaly, and N. J. Besansky, "Anopheles coluzzii and Anopheles amharicus, new members of the Anopheles gambiae complex," Zootaxa, vol. 3619, no. 3, pp. 246-274, 2013.

[9] P. Sharma, S. Khandelwal, T. Singh, and R. Vijayvergia, "Phytochemical Analysis and Antifungal Potential of Duranta erecta against Some Phytopatogenic Fungi," Int. J. Pharm. Sci. Res., vol. 3, no. 8, pp. 2686-2689, 2012.

[10] P. N. Akono et al., "Anopheles gambiae, vecteur majeur du paludisme à Logbessou, zone péri-urbaine de Douala ( Cameroun )," Bull. Soc. Pathol. Exot., vol. 108, pp. 360-368, 2015.

[11] E. J. Mavundza, R. Maharaj, J. C. Chukwujekwu, J. F. Finnie, and J. Van Staden, "Screening for adulticidal activity against Anopheles arabiensis in ten plants used as mosquito repellent in South Africa," Malar. J., vol. 13, no. 173, pp. 1-5, 2014.

[12] N. Moussavi et al., "Identification of chemical constituents of Zanthoxylum heitzii stem bark and their insecticidal activity against the malaria mosquito Anopheles gambiae," Parasites and Vectors, vol. 8, no. 1, pp. 1-8, 2015.

[13] M. K. Oumarou, L. Younoussa, and E. N. Nukenine, "Toxic effect of Chenopodium ambrosoides, Hyptis suaveolens and Lippia adoensis leaf methanol extracts and essential oils against fourth instar larvae Toxic effect of Chenopodium ambrosoides, Hyptis suaveolens and Lippia adoensis leaf methanol extracts a," Int. J. Mosq. Res., vol. 5, no. 1, pp. 61-66, 2018.

[14] A. A. Imam, A. Ibrahim, H. Abdullahi, and A. S. Amosa, "Malaysian Journal of Applied Sciences Comparative Larvicidal Properties and Detoxification Machinery of Bioactive," Malaysian J. Appl. Sci., vol. 3, no. 1, pp. 923, 2018.

[15] H. Suwaiba, A. A. Barde, P. S. Mao, and O. A. Aliyu, "GSC Biological and Pharmaceutical Sciences Larvicidal activity of Ageratum conyzoides L . extracts on Anopheles gambiae complex," GSC Biol. Pharm. Sci., vol. 3, no. 3, pp. 1-5, 2018.

[16] V. T. Sanyaolu, R. O. Awodoyin, and S. Ogunyemi, "A Survey of the Most Common Ornamental Plants in Southwest Nigeria," Pacific J. Sci. Technol., vol. 19, no. 1, pp. 334-343, 2018.

[17] R. Subsongsang and W. Jiraungkoorskul, "An Updated Review on Phytochemical Properties of 'Golden Dewdrop' Duranta erecta.," Pharmacogn. Rev., vol. 10, no. 20, pp. 115-117, 2016.

[18] G. . Prabhakar, P. Kamalakar, T. Ashok Vardhan, and K. Shailaja, "In-Vitro Screening of Antibacterial Activity of Seeds of Crotalaria verrucosa L. and Duranta erecta L.," Eur. J. Pharm. Med. Res., vol. 2, no. 4, pp. 411-419, 2015.

[19] J. E. Agwu, G. E. Odo, F. Ekeh, M. Uwagbae, G. Ngwu, and C. Ehilegbu, "Bioefficacy of Duranta erecta leaf extract on yellow fever and dengue vector, Aedes aegypti Linn . in Nigeria," J. Med. Plants Res. Full, vol. 12, no. 11, pp. 124-132, 2018.

[20] F. Nikkon, Z. A. Saud, K. Hossain, M. S. Parvin, and M. E. Haque, "Larvicidal effects of stem and fruits of Duranta repens against the mosquito Culex quinquefasciatus," Int. J. PharmTech Res., vol. 1, no. 4, pp. 1709-1713, 2009.
[21] M. Z. Norhafizah, B. S. Ismail, and T. S. Chuah, "Herbicidal activity of Pennisetum purpureum ( Napier grass )," African J. Biotechnol., vol. 11, no. 23, pp. 62696273, 2012.

[22] C. C. Okaraonye and J. C. Ikewuchi, "Nutritional and Antinutritional Components of Pennisetum purpureum ( Schumach )," Pakistan J. Nutr., vol. 8, no. 1, pp. 32-34, 2009.

[23] S. S. Rajaram and G. G. Ashvin, "Preliminary Phytochemical Analysis of Leaves of Tridax procumbens Linn .," Int. J. Sci. Environ., vol. 2, no. 3, pp. 388-394, 2013.

[24] C. J. Ikewuchi, C. C. Ikewuchi, and N. M. Igboh, "Chemical Profile of Tridax procumbens Linn," Pakistan J. Nutr., vol. 8, no. 5, pp. 548-550, 2009.

[25] M. C. Rathy, U. Sajith, and C. C. Harilal, "Larvicidal efficacy of medicinal plant extracts against the vector mosquito Aedes albopictus," Int. J. Mosq. Res., vol. 2, no. 2 , pp. 80-82, 2015.

[26] C. Fernanda et al., "Levels of Tannins and Flavonoids in Medicinal Plants: Evaluating Bioprospecting Strategies," Evidence-Based Complement. Altern., vol. 434782, p. 7, 2012.

[27] V. Ghosh, S. Sugumar, A. Mukherjee, and N. Chandrasekaran, Neem ( Azadirachta indica) Oils. Elsevier Inc., 2016.

[28] N. Ivoke, F. Chukwuemenam, and L. Owoicho, "Evaluation of ovicidal and larvicidal effects of leaf extracts of Hyptis suaveolens (L) Poit (Lamiaceae) against Anopheles gambiae (Diptera: Anophelidae) complex," Anim. Res. Int., vol. 6, no. 3, pp. 1072-1076, 2009.

[29] S. Khalid, A. Shahzad, N. Basharat, M. Abubakar, and P. Anwar, "Phytochemical Screening and Analysis of Selected Medicinal Plants in Gujrat," J. Phytochem. Biochem., vol. 2, no. 1, pp. 2-4, 2018.

[30] M. G. Ajuru, L. F. Williams, and G. Ajuru, "Qualitative and Quantitative Phytochemical Screening of Some Plants Used in Ethnomedicine in the Niger Delta Region of Nigeria," J. Food Nutr. Sci., vol. 5, no. 5, pp. 198-205, 2017.

[31] F. Mumtaz and S. M. Raza, "Qualitative phytochemical analysis of some selected medicinal plants occurring in local area of Faisalabad, Pakistan," J. Pharm. Altern. Med., vol. 3, no. 3, pp. 17-21, 2014.

[32] T. M. Bandiola, "Extraction and Qualitative Phytochemical Screening of Medicinal Plants: A Brief Summary," Int. J. Pharm., vol. 8, no. 1, pp. 137-143, 2018.

[33] WHO, Guidelines for Laboratory and Field Testing of Mosquito Larvicides. 2005.

[34] B. Jayalakshmi, K. A. Raveesha, and K. N. Amruthesh, "Phytochemical investigations and antibacterial activity of some medicinal plants against pathogenic bacteria," $J$. Appl. Pharm. Sci., vol. 1, no. 5, pp. 124-128, 2011.

[35] M. M. Serena, M. Balasubramani, K. Rajan, and I. A. J. Gerald, "Evaluation of the larvicidal activity of the leaf extracts of Duranta erecta Linn. ( Verbenaceae ) on the lar vae of Culex quinquefascitatus ( Say ) ( Culicidae)," J. Biopestic., vol. 3, no. 3, pp. 582-585, 2010.

[36] R. Dhanabalan, A. Doss, M. Jagadeeswari, S. Balachandar, E. Kezia, and V. Parivuguna, "In vitro Phytochemical Screening and Antibacterial Activity of Aqueous and Methanolic Leaf Extracts of Tridax procumbens against Bovine Mastitis Isolated Staphylococcus aureus," Ethnobot. Leafl., vol. 12, pp. 
1090-1095, 2008.

[37] S. Christudas, T. M. Kulathivel, and P. Agastian, "Phytochemical and antibacterial studies of leaves of Tridax procumbens L .," Asian Pac. J. Trop. Biomed., vol. 2, no. 1, pp. S159-S161, 2012.

[38] N. Savithramma, M. L. Rao, and G. Bhumi, "Phytochemical screening of Thespesia populnea (L.) Soland and Tridax procumbens L. N.," J. Chem. Pharm. Res., vol. 3, no. 5, pp. 28-34, 2011.

[39] H. O. Edeoga, D. E. Okwu, and B. O. Mbaebie, "Phytochemical constituents of some Nigerian medicinal plants," African J. Biotechnol., vol. 4, no. 7, pp. 685-688, 2005.

[40] A. U. Brantley, J. O. Akaninwor, and A. B. Achor, "Phytochemical Composition and Antidiabetic Properties of Aqueous Stem Extract of Pennisetum purpureum on Alloxan - Induced Diabetic Wistar-Albino Rats," Open Sci. J. Pharm. Pharmacol., vol. 3, no. 6, pp. 72-79, 2015.

[41] O. R. Johnson-Ajinwo and J. Chime, "Mineral Content and Chemical Composition of Napier ( Pennisetum purpureum ) Grass," Saudi J. Med. Pharm. Sci., vol. 4, no. 4, pp. 382-386, 2018.

[42] B. Inalegwu and O. A. Sodipo, "Antimicrobial and foam forming activities of extracts and purified saponins of leaves of Tephrosia vogelii," Eur. J. Exp. Biol., vol. 5, no. 5, pp. 49-53, 2015.

[43] S. D. Desai, D. G. Desai, and H. Kaur, "Saponins and their Biological Activities," Pharma Times, vol. 41, no. 3, pp. 13-16, 2009.

[44] P. Pietta, "Flavonoids as Antioxidants," J. Nat. Prod., vol. 63, pp. 1035-1042, 2000.

[45] I. Hernandez, L. Alegre, F. Van Breusegem, and S. Munne, "How relevant are flavonoids as antioxidants in plants?," Trends Plant Sci., vol. 14, no. 3, pp. 125-132, 2009.

[46] L. A. Weston and U. Mathesius, "Flavonoids: Their Structure, Biosynthesis and Role in the Rhizosphere, Including Allelopathy," J Chem Ecol, vol. 39, pp. 283297, 2013.

[47] L. H. Yao, Y. M. Jiang, F. A. Tomas-Barberan, N. Datta, R. Singanusong, and S. S. Chen, "Flavonoids in Food and Their Health Benefits," Plant Foods Hum. Nutr. 59, vol. 59, pp. 113-122, 2004.

[48] C. Brunetti, M. Di Ferdinando, A. Fini, S. Pollastri, and M. Tattini, "Flavonoids as Antioxidants and Developmental Regulators: Relative Significance in Plants and Humans," Int. J. Mol. Sci., vol. 14, pp. 35403555, 2013.

[49] S. Kumar and A. K. Pandey, "Chemistry and Biological Activities of Flavonoids: An Overview," Sci. J. Vol., vol. 162750, p. 16, 2013.

[50] C. Di et al., "Isolation of flavonoids from Anemopaegma arvense ( Vell ) Stellf . ex de Souza and their antifungal activity against Trichophyton rubrum," Brazilian $J$. Pharm. Sci., vol. 49, no. 3, pp. 559-565, 2013.

[51] R. B. Kshatriyaa and G. M. Nazeruddin, "Bioactive flavonoids of therapeutic importance," 7th Int. Symp. Feed. Recycl. Polym. Mater., no. October, pp. 23-26, 2013.

[52] P. O. Ukoha, E. A. C. Cemaluk, O. L. Nnamdi, and E. P. Madus, "Tannins and other phytochemical of the Samanaea saman pods and their antimicrobial activities," African J. Pure Appl. Chem., vol. 5, no. 8, pp. 237-244, 2011.

[53] E. F. Al-Jumaily, H. A. Abdul-Ratha, and R. H.
Raheema, "Extraction and Purification of Tannins from Plantago lanceolata L. and assessment of their antibacterial activity on pathogenesis of enteropathogenic E. coli in vitro and in vivo," Trends Life Sci., vol. 1, no. 1, pp. 17-21, 2012.

[54] A. V. Pereira, G. M. Santana, M. B. Góis, and D. M. G. S. Ana, "Tannins obtained from medicinal plants extracts against pathogens: antimicrobial potential," Battle Against Microb. Pathog. Basic Sci. Technol. Adv. Educ. Programs, pp. 228-235, 2015.

[55] A. Molan and A. M. Faraj, "The effects of condensed tannins extracted from different plant species on egg hatching and larval development of Teladorsagia circumcincta (Nematoda: Trichostrongylidae)," Folia Parasitol. (Praha)., vol. 57, no. 1, pp. 62-68, 2010.

[56] C. M. Furlan, L. B. Motta, and D. Santos, "Tannins: What do they represent in plant life?," in Tannins: Types, Foods Containing, and Nutrition, no. Chapter 10, 2010, pp. 1-13.

[57] S. Dhanasekaran, K. Krishnappa, A. Anandan, and K. Elumalai, "Larvicidal, ovicidal and repellent activity of selected indigenous medicinal plants against malarial vector Anopheles stephensi ( Liston .), dengue vector Aedes aegypti ( Linn .) and Japanese encephalitis vector , Culex tritaeniorynchus ( Giles .) ( Dipt," J. Agric. Technol. 2013, vol. 9, no. 1, pp. 29-47, 2013.

[58] M. Govindarajan, A. Jebanesan, and T. Pushpanathan, "Larvicidal and ovicidal activity of Cassia fistula Linn . leaf extract against filarial and malarial vector mosquitoes," Parasitol. Res., vol. 102, pp. 289-292, 2008.

[59] C. Panneerselvam, "Adulticidal, repellent, and ovicidal properties of indigenous plant extracts against the malarial vector, Anopheles stephensi ( Diptera: Culicidae )," Parasitol. Res., vol. 112, pp. 679-692, 2013.

[60] G. Marimuthu and S. Rajamohan, "Larvicidal and ovicidal properties of leaf and seed extracts of Delonix elata ( L .) Gamble ( Family : Fabaceae ) against malaria (Anopheles stephensi Liston) and dengue (Aedes aegypti Linn .) ( Diptera: Culicidae ) vector mosquitoes," Parasitol. Res., vol. 111, pp. 65-77, 2012.

[61] L. Younoussa, E. N. Nukenine, and C. O. Esimone, "Toxicity of Boswellia dalzielii (Burseraceae) Leaf Fractions Against Immature Stages of Anopheles gambiae (Giles) and Culex quinquefasciatus (Say) (Diptera: Culicidae).," Int. J. ilsect Sci., vol. 8, pp. 2331, 2016.

[62] S. Cheah, J. Tay, and L. Chan, "Larvicidal, oviposition, and ovicidal effects of Artemisia annua (Asterales: Asteraceae ) against Aedes aegypti, Anopheles sinensis , and Culex quinquefasciatus ( Diptera: Culicidae )," Parasitol. Res., vol. 112, pp. 3275-3282, 2013.

[63] G. Elango, A. Bagavan, C. Kamaraj, A. Abduz Zahir, and A. AbdulRahuman, "Oviposition-deterrent, ovicidal, and repellent activities of indigenous plant extracts against Anopheles subpictus Grassi ( Diptera : Culicidae )," Parasitol. Res., vol. 105, pp. 1567-1576, 2009.

[64] Government of Western Australia Department of Water, "Aerial spraying of crops with pesticides," no. February, pp. 1-26, 2010.

[65] M. Govindarajan, A. Jebanesan, and T. Pushpanathan, "Studies on effect of Acalypha indica L. (Euphorbiaceae ) leaf extracts on the malarial vector, Anopheles stephensi Liston ( Diptera : Culicidae )," Parasitol. Res., vol. 103, pp. 691-695, 2008. 
[66] B. M. Maniafu, L. Wilber, I. O. Ndiege, C. C. Wanjala, and T. A. Akenga, "Larvicidal activity of extracts from three Plumbago spp against Anopheles gambiae," Rio Janeiro, vol. 104, no. 6, pp. 813-817, 2009.

[67] J. M. Adesina, A. R. Jose, Y. Rajashekar, and K. D. Ileke, "Persea americana ( Mill .) seed extracts: Potential herbal larvicide control measure against Anopheles gambiae Giles , 1902 ( Diptera: Culicidae ) Malaria vector," Int. J. Mosq. Res., vol. 3, no. 2, pp. 14-17, 2016.

[68] C. F. Araonu, A. C. . Ike, and G. I. Ngwu, "Larvicidal effects of crude methanolic and n-hexane extracts of Cymbopogon citratus and Ocimum gratissimum on Anopheles gambiae mosquito," Niger. J. Parasitol., vol. 39 , no. 1, p. 169110, 2018.

\section{Publish your books with AIJR publisher-}

- Publish with ISBN and DOI.

- Publish Thesis/Dissertation as Monograph.

- Publish Book Monograph.

- Publish Edited Volume/ Book.

- Publish Conference Proceedings

- Retain full copyright of your books.

Submit your manuscript at books.aijr.org

\section{Publish your research article in AIJR journals-}

- Online Submission and Tracking

- Peer-Reviewed

- Rapid decision

- Immediate Publication after acceptance

- Articles freely available online

- Retain full copyright of your article.

Submit your article at journals.aijr.in 